International Journal of STEM Education for Sustainability, Vol 2, No.1, 2022, pp. 133-139 e-ISSN 2798-5091. DOI. 10.53889/ijses.v2i1.52

\title{
Indonesian Science Teachers' Ability to Design Scientific Literacy Test
}

\author{
Submitted 19 November 2021 Revised 4 January 2022 Accepted 4 January 2022 \\ ${\text { Riskan } \text { Qadar }^{1 *} \text {, Zeni Haryanto }}^{2}$, Lambang Subagiyo ${ }^{3}$, Muhammad Junus ${ }^{4}$, Muliati Syam ${ }^{5}$ \\ 1,2,3,4,5 Department of Physics Education, Faculty of Teacher Training and Education, \\ Universitas Mulawarman, Samarinda, Indonesia \\ Corresponding Email: *riskanqadar@fkip.unmul.ac.id
}

\begin{abstract}
The ability of junior high school teachers to design scientific literacy tests is necessary. This research is focused on finding out how teachers can elaborate their ability to design scientific literacy tests. There are eight indicators related to scientific literacy in the developed instrument. We analyzed 41 packages in junior high schools from 9 regencies/cities in Indonesia. Based on the analysis, it was found that there were indicators that had not been achieved because curriculum materials were not available in that semester. This study shows that Indonesian science teachers can develop tests containing scientific literacy with an average of $76.4 \%$ of all scientific literacy indicators.
\end{abstract}

Keywords: Assessment, Scientific literacy, Science teacher, Local energy source.

\section{INTRODUCTION}

The development of science in the 21 st century is moving like an exponential trajectory. This can be seen that our existence is already in the era of the industrial revolution 4.0. The rapid development of science is literacy for teachers in schools. Scientific literacy is the result of technology from outside, but how to see the natural potential of the environmental area where teachers and students are located and how to develop it. In education, teachers are required to implement the next generation of science standards (National Research Council, 2013, 2014, 2015). One of them is how to see the teacher's ability to design tests. This instrument is used to measure student's progress within a certain period.

The province of East Kalimantan, Indonesia which is located in the tropics, produces abundant natural resources and has its uniqueness. The paradigm that must be built in developing scientific literacy in students in tropical forest environments is that students can maintain regional ecosystems, innovate in tropical forest environmental management, and sustainably develop tropical forest environments. On the other hand, the development and development of the industry that continues to grow have implications for the increasing demand for energy in Indonesia. The energy demand is mostly supported by non-renewable fossil energy. Its reserves continue to run low and impact air pollution, global warming, climate change, rising sea levels, and others. Mining activities also produce very high GHG. The impact of mining is that Carbon Dioxide $\left(\mathrm{CO}_{2}\right)$, Nitrogen Dioxide $\left(\mathrm{NO}_{2}\right)$, and methane $\left(\mathrm{CH}_{4}\right)$ are produced mainly from the emission process during open dumping and transportation processes.

So far, the paradigm that has developed is that natural resources in Indonesia are abundant and cannot be exhausted. This can cause the majority of people to feel guilty about exploiting natural resources as much as possible and disposing of waste into environmental media. The impact of this behavior is currently quite heavy environmental damage and causes a decrease in the carrying capacity of nature. The trend of declining environmental quality is increasingly concerning. Various disasters, 
International Journal of STEM Education for Sustainability, Vol 2, No.1, 2022, pp. 133-139 e-ISSN 2798-5091. DOI. 10.53889/ijses.v2i1.52

such as floods, droughts, decreased soil fertility, water scarcity, loss of a number of vegetation is a portrait of the decline in environmental quality due to irresponsible exploitation of SDA (Natural Resources).

Various further impacts from the use of natural resources, especially the exploitation of the mining sector that has been felt, include increased carbon emissions, critical land, floods, increased sedimentation rates, and changes in micro-climate. These impacts can directly or indirectly disrupt agricultural productivity to affect further food security and changes in economic, social, and cultural structures. Therefore, teachers and students must have good scientific literacy about tropical forests and their environment. This is where science teachers play a very important role in building a good paradigm about tropical forests and their environment.

Everyone needs to have the ability to deal with important issues in science and technology. Along with the increasing importance of scientific literacy. Many countries have invested heavily in creating scientifically literate work incentives (Rustaman, 2020). The term scientific literacy was first introduced by Hurd in 1958 (National Academies of Sciences, Engineering, and Medicine, 2016) and has now penetrated a lot in the public discourse on science education. Scientific literacy is the capacity to use scientific knowledge, identify questions, and draw conclusions based on evidence to understand and help make informed decisions relationship with nature and its changes due to human activities (OECD, 2016). PISA develops three dimensions of scientific literacy: scientific concepts, scientific processes, and scientific situations and application areas. The dimensions of scientific literacy in the measurement consist of science content, scientific process, and the context of science application.

The dimensions of scientific literacy that PISA has set require that these three dimensions be applied in education. In the context of the application of science, there are natural resources and the environment. The scope of the content and process dimensions relates to the assessment area used.

The scientific literacy questions in PISA have several characteristics: First, the questions are not directly related to the curriculum but are more expanded. Second, the question is given information that requires students to answer it. Third, ask students to process the information contained in the questions. Fourth, the statement that accompanies the question in the problem that needs to be analyzed. Fifth, the questions are made in various forms, such as multiple-choice, short entry, or essay. Sixth, the questions cover application contexts such as personal-communication-global, life-health-earth, and rich technology environments.

Based on the characteristics above, it can be developed into eight research indicators. The eight indicators are as follows: 1 . Teachers are expected to design questions by adopting existing energy sources in their respective areas. 2. The questions are written are in the context of the application of global community, life-health-earth, and environment-technology in life in their respective regions. 3. In this case, the answer to the desired question has a relationship with the statement described. 4. In this case, answering the question needs to do an analysis first. 5. The teacher must make questions according 
International Journal of STEM Education for Sustainability, Vol 2, No.1, 2022, pp. 133-139

e-ISSN 2798-5091. DOI. 10.53889/ijses.v2i1.52

to the type that has been selected. 6 . The questions are related to everyday life. 7 . The subject matter is still relevant for the next 10 years. 8 . The questions written are not only rote but require understanding, application, analysis, evaluation, and creativity. From the description above, the application of scientific literacy in the tropics is knowledge about natural resources that need to be informed to students. The goal is that students can understand well scientific literacy in their area. This is very closely related to the teacher's ability to write scientific literacy tests. Natural resources in various provinces vary, including: in East Kalimantan, there are coal, oil, natural gas, and tropical forests.

A number of junior high school science teachers in East Kalimantan were met to determine their ability to design scientific literacy tests. The interview results show that most teachers in the making tests are not based on scientific literacy but are only based on copy-pasting from existing tests taken from the national exam results. Most of the research that has been done has only made tests in the cognitive, affective, psychomotor, critical thinking skills, and creative thinking skills. Several studies include: Rosidin and Suyatna (2020) making tests to assess students' skills in real laboratory-based science learning; Rochman and Hartoyo (2018) created an instrument to analyze students' higher-order thinking skills based on Bloom's taxonomy, and Bashooir and Supahar (2018) validated and relied on the instrument made to measure scientific literacy performance in STEM-based physics learning.

Problems regarding the capability of science teachers in East Kalimantan in terms of scientific literacy and the ability to develop scientific literacy tests are still low. This is marked by the teacher's performance implemented in front of the class and the lack of tests that involve scientific literacy, especially scientific literacy based on local wisdom and other uniqueness where teachers and students are located. Therefore, it is necessary to research to measure the ability of junior high school science teachers' ability to make scientific literacy tests based on local wisdom. In addition, it will also be known whether the tests made are also by the characteristics of scientific literacy in PISA. The urgency of this research is to investigate the capability of teachers and students as future generations in understanding and to manage natural resources in a tropical environment.

\section{METHOD}

This study began with the desire to elaborate on the ability to design scientific literacy tests for science teachers at junior high schools in East Kalimantan, Indonesia. Furthermore, a characteristic instrument design for scientific literacy questions was made based on PISA and scientific literacy on energy sources in East Kalimantan.

This research is divided into three stages: initial preparation, research implementation, and research results. In the literature/field study, they were namely looking for information about tests that have been used created by science teachers in the tropics. The field data is in the form of giving a questionnaire to determine the teacher's ability to write scientific literacy tests and examples of the latest tests made in their schools. The population in the study were all junior high school science teachers for 
International Journal of STEM Education for Sustainability, Vol 2, No.1, 2022, pp. 133-139 e-ISSN 2798-5091. DOI. 10.53889/ijses.v2i1.52

all districts in East Kalimantan. The samples used were a number of scientific literacy questions from science teachers in each district of East Kalimantan who made scientific literacy tests.

The subject of this study involved all science literacy test tests for junior high school science teachers in East Kalimantan. Of the ten cities/regencies in East Kalimantan, only nine cities/regencies have successfully obtained data, namely Samarinda City, Balikpapan, Bontang, Kukar, Kubar, Kutim, Berau, PPU, and Paser Regencies. Mahulu Regency did not have time to obtain data due to distance and poor communication.

Nine cities/districts that were selected as subjects were randomly sampled with th school SMPN 10, 5) SMPN 16 2. City of Balikpapan, consisting of: 1) SMPN 3, 2) SMPN 4, 3) SMPN 3, 4) school 4, 5) school 5, 3. Bontang City, consisting of: 1) school 6, 2) school 7, 3) school 8, 4) school 9, 5) school 10. 4. Berau Regency, consisting of: 1) school 11, 2) school 12, 3) school 13, 4) school 14, 5) school 15. 5. West Kutai Regency, consisting of: 1) school 16,2) school 17, 3) school 18, 4) school 19, 5) school 20. 6. Kutai Kartanegara Regency, consisting of: 1) school 21, 2) school 22, 3 school 23, 4) school 24, 5) school 25. 7. North Penajam Paser Regency (PPU), consisting of: 1) school 26, 2) school 27, 3) school 28, 4) school 29, and school 20. 8. Paser Regency, consisting of: all SMP in Paser Regency using the instrument same science problem. 9. East Kutai Regency, consisting of: 1) school 21,2) school 22, 3) school 23, 4) school 24, 5) school 25.

The variables measured in this study are indicators of scientific literacy which were developed into eight, namely: 1. Contains concepts that are expanded from the curriculum (regional energy sources). 2. Covers the context of personal-community-global, life-earth-health, and technologyenvironment applications. 3. There is a relationship of information relationship to the answer to the question. 4. Answers to questions need to be done analytically. 5. Types of multiple choice questions, short entries/essays. 6. Relevant to everyday life. 7. Knowledge has a relevance grace period of at least ten years into the future. 8. Related to the process of science, not memorization.

This research model is a qualitative research. The data used is a question instrument written by a science teacher for the final semester exam of class VIII. The number of tests collected was 41 from nine districts and cities. The data needed in this research are in the form of quantitative data and qualitative data. Quantitative data is used to determine the percentage of scientific literacy indicators on science question tests made by science teachers. Qualitative data was used as a literature and field study. Based on the research subjects that have been determined, the collection of science question tests used by teachers in the summative test of the even semester of the 2020/2021 school year is carried out. The number of tests collected was obtained from 41 junior high schools in East Kalimantan. The eight district cities were represented by five schools each and Kabupaten Paser used the same single instrument for all SMP. The data collected from 41 science questions were analyzed descriptively to find the percentage of indicators included in scientific literacy. 
International Journal of STEM Education for Sustainability, Vol 2, No.1, 2022, pp. 133-139 e-ISSN 2798-5091. DOI. 10.53889/ijses.v2i1.52

\section{RESULTS AND DISCUSSION}

The data collected is the teacher's ability to write scientific literacy questions which consists of eight indicators. The use of these eight indicators can be seen in the tests written by the teachers as shown in Table 1.

Table 1. Percentage of Science Literacy Questions per city/district in East Kalimantan

\begin{tabular}{|c|c|c|c|c|c|c|c|c|c|c|}
\hline \multirow[t]{2}{*}{ No. } & \multirow{2}{*}{$\begin{array}{l}\text { City/ } \\
\text { District }\end{array}$} & \multicolumn{8}{|c|}{ Indicator Percentage } & \multirow{2}{*}{$\begin{array}{c}\text { Average } \\
\%\end{array}$} \\
\hline & & 1 & 2 & 3 & 4 & 5 & 6 & 7 & 8 & \\
\hline 1 & Samarinda & 0 & 100 & 100 & 20 & 100 & 100 & 100 & 100 & 77,5 \\
\hline 2 & Balikpapan & 0 & 100 & 80 & 20 & 100 & 100 & 100 & 100 & 75 \\
\hline 3 & Bontang & 0 & 100 & 100 & 60 & 100 & 100 & 100 & 100 & 82,5 \\
\hline 4 & Kukar & 0 & 100 & 100 & 60 & 100 & 100 & 100 & 80 & 80 \\
\hline 5 & Kubar & 0 & 100 & 40 & 0 & 80 & 100 & 100 & 100 & 65 \\
\hline 6 & Kutim & 0 & 100 & 100 & 20 & 100 & 100 & 80 & 60 & 70 \\
\hline 7 & Berau & 0 & 100 & 100 & 0 & 100 & 100 & 100 & 20 & 65 \\
\hline 8 & Paser & 0 & 100 & 100 & 100 & 100 & 100 & 100 & 100 & 87,5 \\
\hline 9 & PPU & 0 & 80 & 100 & 100 & 100 & 100 & 100 & 100 & 85,0 \\
\hline $\begin{array}{l}\text { Ave } \\
\text { perce }\end{array}$ & $\begin{array}{l}\text { ge } \\
\text { age }\end{array}$ & 0 & 97,2 & 91,1 & 42,2 & 97,8 & 100 & 97,8 & 84,4 & 76,4 \\
\hline
\end{tabular}

Based on the data described for each city/district above, it can be said that the characteristics of the tests developed by the science teachers of junior high schools in Indonesia have mostly followed the indicators developed. These characteristics follow the appropriate teaching materials. The first indicator is the expansion of the curriculum related to energy sources. However, this semester, the science teacher did not include it in the science instrument because the material did not exist. For the second indicator, which provides for personal-community-global applications, life-health-earth, and environmenttechnology as a whole, $97.2 \%$ is fulfilled. The third indicator, which includes the relationship of information to the answers to the questions as a whole, reached $91.1 \%$. The fourth indicator, which includes answers, needs to be done analytically—overall fulfilled by $42.2 \%$. This small percentage is because the level of understanding and application dominates the questions written by the teacher. The fifth indicator includes the type of questions in the form of PG and/or short entries/essays fulfilled by $97.8 \%$. The sixth indicator consists of the existence of relevance in everyday life is fulfilled by $100 \%$. The seventh indicator includes a grace period of at least ten years of significance in the future. Overall fulfilled by $97.8 \%$. And finally, the eighth indicator contains questions that are above memorizing or remembering fulfilled by $84.4 \%$. These indicators include understanding and application levels.

The test for scientific literacy questions from Junior High Schools and equivalents in each Regency and City on the first indicator regarding scientific literacy on energy sources was not fulfilled because there were no such teaching materials in the even semester of grade VIII. The second indicator covers the context of personal-community-global, life-health-earth, and technology-environment 
International Journal of STEM Education for Sustainability, Vol 2, No.1, 2022, pp. 133-139 e-ISSN 2798-5091. DOI. 10.53889/ijses.v2i1.52

applications. Some wrote questions about global warming, about how to maintain ear health when loud noises are heard, and about respiratory health. The third indicator, there is a relationship of information for the answers to questions; on average, write questions that have to do with the statement of the question item. The fourth indicator, the answers to questions, need to be done analytically. The teachers write down analytical category questions about how to analyze the laboratory experiments' results. The fifth indicator, type of PG questions, short entries/essays, all write multiple-choice questions, and according to the desired category. The sixth indicator, relevant to everyday life, writes questions about everyday life. Examples of questions include applying Pascal's law in car washes and car jacks, sight, sound, mirrors, and applying inclined planes, energy, and health. The seventh indicator, knowledge has a relevance grace period of at least 10 years into the future. The average teacher designs questions that have a minimum utilization grace period of ten years into the future. The eighth indicator, related to the non-memorization process of science, the average teacher writing questions is still associated with the level of understanding, application application, and analysis.

Teaching materials dominate the tests developed by science teachers in Indonesia. Concerning local wisdom has not been seen because teaching materials about energy sources in that semester are not being taught.

\section{CONCLUSION}

This study reveals the ability to design scientific literacy tests for Indonesian junior high school science teachers. The characteristics of the tests developed by science teachers at junior high schools in Indonesia have followed the indicators of scientific literacy tests except that the indicators contain concepts extended from the curriculum, and the answers to questions are in the form of analysis. As for each district city, the indicators are fulfilled in various ways. The tests developed by the teacher are reflected following the teaching materials. Still, the tests that reflect local wisdom have not been seen because the teaching materials about energy sources are not being taught.

\section{REFFERENCES}

Bashooir, K., \& Supahar, S. (2018). Validitas dan reliabilitas instrumen asesmen kinerja literasi sains pelajaran fisika berbasis STEM. Jurnal penelitian dan evaluasi pendidikan, 22(2), 219-230.

National Academies of Sciences, Engineering, and Medicine. (2016). Science literacy: Concepts, contexts, and consequences.. The National Academies Press.

National Research Council (2013). Next Generation Science Standards: For States, By States. The National Academies Press.

National Research Council. (2014). Literacy for Science: Exploring the Intersection of the Next Generation Science Standards and Common Core for ELA Standards: A Workshop Summary. The National Academies Press. 
International Journal of STEM Education for Sustainability, Vol 2, No.1, 2022, pp. 133-139

e-ISSN 2798-5091. DOI. 10.53889/ijses.v2i1.52

National Research Council. (2015). Guide to Implementing the Next Generation Science Standards. The National Academies Press.

OECD, I. (2016). Energy and air pollution: world energy outlook special report 2016.

Rochman, S., \& Hartoyo, Z. (2018). Analisis high order thinking skills (HOTS) taksonomi menganalisis permasalahan fisika. SPEJ (Science and Physic Education Journal), 1(2), 78-88.

Rosidin, U., \& Suyatna, A. (2019). Pengaruh penerapan instrumen performance assessment pada pembelajaran IPA berbasis laboratorium real terhadap hasil belajar siswa. Jurnal Penelitian Pendidikan IPA, 6(1).

Rustaman, N. et al. (2020). Materi dan Pembelajaran IPA SD. Tangerang Selatan. Universitas Terbuka. 